\title{
On the Marketisation of University Education in Britain
}

\section{Huan Chen}

\author{
Guilin Normal College, Guangxi, 541001
}

\begin{abstract}
The word marketisation derived from the description of the government behavior involving selling government agencies, government services and assets and encouraging private enterprises. There are different forms of marketisation in higher education. In the system of marketisation, British government has acted as investors and buyers while investment objective and the service providers are institutions of higher learning. This paper also analised major contents of market reform in Britain, and the effects of marketisation reform in British universities, both positively and negatively.
\end{abstract}

\section{Key words- marketisation, higher education, Britain}

\section{INTRODUCTION}

The word of marketisation came from the description of the government behavior, involving selling government agencies, government services and assets, and encouraging private enterprises. Facing the greatly increasing cost in higher education, many governments seek to decrease financial burden of higher education by encouraging the development of private universities, and introducing market-oriented behaviors of private enterprises, such as tuition, commodities and service selling, in order to increase the social and economic efficiency of higher education.

\section{Forms of marketisation}

Different forms of marketisation will be distinguished, described and analyzed one by one in the following paragraphs.

Tuition is the money that students or students' family pay for their education. It is a characteristic in most western colleges and universities for several centuries. However, till later part of $20^{\text {th }}$ century, colleges and universities of many countries followed the new policy of free education in the United States and some other countries. The policy is based on the assumption that, to a large degree, education belongs to public interests and should be distributed fairly and extensively. Of course it is sometimes a doubt that students' free entrance to universities will weaken both students and schools' decision and awareness of competition. There are different ways of charging, while at least the purpose of charging is the same. Charging of school fees is complicated, but there are some main ways of marketisation and expected results, which are briefly summarized here.

Briefly, people expect students to pay a large amount of money for education service. Universities can benefit from the increasing income or some other sources such as tax from taxpayers, or schools' donation in order that teaching staff can also benefit from it, and schools' financial burden can be lowered. Sometimes, people expect to create or strengthen market mechanism in education system in order to make students more desirable to learn. And schools become more efficient and responsible providers of education service. Different from the capital from country or other donors, fee income, as a whole, has no a predetermined specific expenditure purpose. But 
it provides opportunity for the growth of school autonomy.

Once market and social justice hang a hook, marketisation becomes complicated. If higher education has its personal profit and those who occupy social economic advantages may get the chance. But schools pay the fees, the majority of the taxpayers paying cost that does not enjoy the private benefits can be regarded as a fair selection. Scholarships and loans also play a part in the negative social returns. Costs paid by the government through students' agency, such as educational reference, which was carried out in Britain, or frequently proposed but rarely completed, may intend to create a marketisation method of the simulation of the market. Students are funded by the government and act as the role of consumers similar to that in a free market system. Schools are supposed to respond with the business type. Contrary to the income of grant, the more money schools get from the cost, the larger degree the anticipation of the market or the market behavior will be.

\section{Higher education institutions and Marketisation}

Marketisation of higher education makes its institutions more and more like a hybrid organization. In higher education practice, besides traditional teaching and research, universities also carry out all kinds of educational contracts and research projects to increase schools' income. In the words of Van Twist \&I n'tveld: It is such an entity that operates between the public and private domains, performs public responsibility, and is involved in a variety of commercial market activities. It becomes a mixture of government agency and commercial enterprises, which is born with a characteristic of both positive and negative aspects. On one hand it is seen as a more consumer tendency, effective, and innovative organization. On the other hand, it is easy to go to the negative direction so that some social and educational problems arouse.

Therefore, the two experts analyze and summarize the advantages of this hybrid mechanism: (1) Be able to do better because they have to compete with other institutions; (2) Willing to make new reform and development in order to get more features; (3) Focus on internal coordination, make it more market-oriented, and emphasize on efficiency; (4) Own the enterprise-oriented attitude towards educators, and make more efforts to improve the efficiency of the production process and product quality; (5)Implement common tasks with less cost to earn extra income; (6) Meet the demands of the market through the operation of business activities; (7) Be able to enhance the enthusiasm of the staff and to increase income.

\section{Major contents of market reform in Britain}

In recent twenty years, Britain with market as the center, has taken many measures in higher education reform. Among them are: reduce the funding in higher education and; introduce competition concept; make use of the stimulus of funding, form a contractual relationship between the government and institutions of higher learning to promote the non-governmental resources revenue; continuously reform and improve higher education funding bodies and mechanisms, make efforts to cut down cost, and strengthen the contractual relationship between government and institutions of higher education; strive to create a fair competition environment and further improve the market; raise the charging standards in accordance with the principle of beneficiary sharing education cost; abolish new 
recruits teacher tenure etc. All these measures make British higher education more rapidly into a market positioning system. This system includes: firstly, higher education and other education branch compete for government funding. Some man-made factors often play a part in this respect. But marketisation reform makes the market incentive; the expected return rate of economic development, as well as other standard becomes the important decision power for educational branch accessing to government funding. Secondly, the core of Government Funding Committee is based on the existing number of students, as well as the expected number of students at a lower average cost. Thirdly, there is a principle about the fund allocation among colleges and teaching staff. It mainly means the number of students in that college. But there are also some other rules, such as the encouragement to recruit foreign students, which brings more benefits and the incentive to attract research project with good sponsorship. Fourthly, there is a rapid increase of non-tenured employees on the bases of free workers engaging in special teaching and research. Fifthly, Colleges and universities have additional resources in the logistics and services, such as student meal services, cleaning services, and housing repairs. Sixthly, Institutions of higher learning participate in social services usually in the form of providing consultant services, including foreign trade of materials and equipment(provide accommodation for conference participators), as well as selling the services of library, laboratory etc.

In the system of marketisation, British government has acted as investors and buyers while investment objective and the service providers are institutions of higher learning. Colleges and universities must rely on the service efficiency and quality that they can provide to obtain the corresponding fund. Therefore, the market here is different from the pure market. It is a quasi market. It occurs in all aspects of higher education, sometimes overlapped with real market.

\section{Effects of marketisation reform in British universities \\ 5.1 Self-centered mode to the consumer-centered mode}

In recent twenty years, market reform has obviously changed the UK higher education. In addition to quantitative development, the UK higher education has gradually transformed from self-centered mode in the past to the consumer-centered mode, with its focus more on teaching, scientific research and the quality and efficiency of other services. It actively strengthens the relationship with society, and achieves the educational purpose of less cost and more education. It is no doubt that the market competition mechanism has played a booster effect for the development of mass higher education in Britain.

\subsection{Changes in management}

Specific to each institution of higher education, market-oriented reform has mainly brought the following changes in management: the funding that school can decide to use decreases rapidly; all the expenses are strictly managed and regulated by relevant departments; all the expenses are based on price contract; a specialized revenue generating department is established; establish the idea of serving the community, and graduates with great abilities are absorbed into the team of teachers, especially those subjects which has very high demand outside the higher education. The situation in 2003 shows that more than $60 \%$ universities admit having teacher recruitment 
difficulties. Thus, the quality of British university teachers is or will be deteriorating.

\subsection{Negative effects}

Market reform in British higher education brings vitality and efficiency. At the same time, it also brings some negative effects. The details are as follows:

Firstly, in determining the direction of the higher education development, it is easy to pay attention to the short-term benefits, while ignore the long-term benefit.

Due to the severe competition, temporary market needs may replace the intrinsic needs of the development of higher education and plays a decisive role so that the slow and high risk projects are difficult to obtain adequate investment and this will endanger the development of fundamental education.

Secondly, the preparation for competition causes a waste of educational resources. In order to obtain more funds for education, the institutions of higher education spend much time, material, manpower, and financial resources to prepare for the competition, causing some waste of educational resources.

Thirdly, university autonomy is violated. For example, government establishes a special organization to supervise the quality of university teaching, which makes the university autonomy threatened seriously. To remain autonomy, the only outcome for universities in Britain is to seek as many non-governmental resources as possible to raise funds via various channels.

Fourthly, teaching quality is threatened. In the British tradition of elite higher education, occupation integrity is very important to ensure the quality of the education. Universities make every effort to focus on quality to maintain a good reputation. In market terms, this can be seen as a long-term market strategy. Under the guidance of this strategy, universities pay more attention to ensure their long-term reputation, rather than short-term benefits. However, in the fierce competition in the market, long-term reputation must rely on short-term benefit and survival. In order to take the short-term benefit into consideration, Institutions of higher education would easily neglect or hardly save long-term reputation. Due to the large scale expansion of higher education, the quality of teaching is under threat. To solve this problem, the British government strengthens the quality supervision and guarantees mechanism in the reform.

\section{Conclusion}

The marketisation reform achievement of British higher education is remarkable, but it also brings some new problems. It is easy to cause the phenomenon of paying attention to short-term benefits and ignoring long-term benefit; the institutions of higher education waste a large number of educational resources to prepare for the competition. Finding solution to these problems should be the direction that the future reform and development of British higher education are striving forward.

\section{Acknowledgement}

This paper is part of the research results of Teaching Reform Project of Higher Education in Guangxi(A). Project Number: 2014JGA289.

\section{Reference}

[1] Chai Na. Eighties and Nineties saw the market-oriented reform of UK higher education[N]. 2009.

[2] Gareth Williams. The market route to mass higher education British experience 
1979-1996[J]. Higher Education Policy, 1997(Vol.10. 275-289.

[3] Ma Fengqi. Higher Education and Market: Problems and Framework.[J] Journal of Higher Education.[J]. 2009 No.1: 31-41
[4] [Wang Lihua. Higher Education: Cost-recovery of England--Quasi marketisation "Strategy and its Effects". Comparative Educatin Review. [J]. 2007 No.2. 42-47. 